\title{
The Influence of Entrepreneurship Education and Entrepreneurial Attitude on Juvenile Prisoner's Entrepreneurial Intention in 3 Provinces of Indonesia
}

\author{
Bobby Hamenda ${ }^{1}$, Andress Hamenda ${ }^{2}$ \\ ${ }^{1}$ Universitas Negeri Manado, Indonesia \& Australian National University, Australia \\ ${ }^{2}$ Punya Harapan, Indonesia \& Coventry University, The United Kingdom
}

\begin{tabular}{ll}
\hline ARTICLE INFO & ABSTRACT \\
\hline Publication Online: & This study discovers the influence of entrepreneurship education on juvenile prisoners' \\
& entrepreneurial intentions in LPKA Batam, Pangkalpinang and Medan located in 3 provinces in \\
& Indonesia while also evaluating their entrepreneurial attitude as a mediating variable. An \\
& examination was held based on the 30 surveys collected to assess for the relationships. It is exhibited \\
& that entrepreneurship education in the 3 juvenile prisons significantly impacts on juvenile prisoners' \\
& entrepreneurial intentions through the crucial roles of entrepreneurial attitude. The findings revealed \\
& that entrepreneurship education influences entrepreneurial intentions indirectly through \\
& entrepreneurial attitude in which its role is a complete mediation to entrepreneurial intentions. The \\
& results also recommended that government of Indonesia with their influential policy can embrace \\
& entrepreneurship education to form juvenile prisoners' entrepreneurial attitude to improve young \\
& prisoners' entrepreneurial intentions. Additionally, the strategic value of these findings is also as the \\
& resource to encourage government, academicians, enterprises with their corporate social \\
& responsibility, and community at large to play their roles in improving entrepreneurship education \\
for juvenile prisoners in Indonesia.
\end{tabular}

KEYWORDS: Entrepreneurship Education, Entrepreneurial Attitude, Entrepreneurial Intentions, Indonesian Juvenile Prisons.

\section{INTRODUCTION}

Juvenile prison which is called LPKA in Indonesia is a place for young persons to serve a sentence within the time period that has been decided in the court process. Placing someone in prison is intended not only to provide a deterrent effect but also to provide guidance so that those who are in it will not be in trouble with the law again after they finish their sentence. However, it is undeniable that one of the biggest problems of these imprisoned individuals is their persistent status as criminals when they return to society. Ex-criminals who want to find work feel discriminated because they have to be excluded from other potential workers because of their criminal record status. Various organizations from outside the prison are trying to solve this problem by providing other routes for ex-prisoners to be able to work independently and thus, various entrepreneurship education is provided for young inmates. However, the main problem is that the effectiveness of the role of standardized entrepreneurship education programs has never been studied because they do not have standard entrepreneurship programs.

The problem of the role of entrepreneurship education in prisons is complex and cannot be solved only by poorly prisoners in Indonesia has long been neglected in juvenile prisons (LPKA) throughout Indonesia. The condition of the inmates' mindset is not immediately assessed when they arrive at LPKA. Facilitators inside or outside the prison provide workshops and training without assessing juvenile prisoners' interests and talents. Juvenile prisoners have very receive a proper education at all. Therefore, young prisoners do not acquire the essential knowledge and skills needed in the workplace or as a provision for them to be able to start independent businesses after they have served their sentence in prison. As a result, they are unable to get a proper job because they are not ready to enter the workplace or run their own business after being released from LPKA. This condition will have a negative impact on their thoughts, emotions and attitudes which can also lead to other criminal acts in the future. It is also known that experts from various fields of study have never conducted research to define the real problem in the prison education system. Prisons do not have standards and policies that allow prisoners to get the appropriate education. Therefore, research is needed to determine the effect of entrepreneurship education for limited access to education and the majority of them never 
prisoners so that the main stakeholders can then find out how influential the entrepreneurship education carried out in prisons generates inmates' entrepreneurial intention to become entrepreneurs.

The results of this study will greatly contribute to juvenile prisons' career in Indonesia because they can pursue independent career paths as an entrepreneur and have no difficulty in finding work after they are released. To work in a company, those who have been in trouble with the law, can experience discriminatory attitudes from prospective employers, so by developing an entrepreneurial mindset, these prisoners whose career paths have been stopped, can begin to form attitudes and mindsets to rebuild their future. Therefore, this study aims to determine the influence of entrepreneurship education on changing the mindset and motivation of inmates in LPKA Batam, LPKA Pangkalpinang and LPKA Medan to be an entrepreneur. The sampling technique in this research is purposive sampling. Even though prisons are difficult to access by outsiders, this research will collaborate with Punya Harapan (CSO) as a partner of the British Embassy Jakarta who has a unique opportunity and relationship which can provide access to juvenile prisons located in 3 provinces in Indonesia (Riau the Island, Bangka Belitung the Island, and North Sumatera).

\section{LITERATURE REVIEW}

Entrepreneurship education is a teaching process so that the knowledge, skills, attitudes and personal character of those who receive education increase in planning and starting a business independently (Hussain \& Norashidah, 2015). Entrepreneurship education varies in context and includes post-secondary school-related courses, as well as traditional 2-4-year undergraduate degree courses either inside or outside business school (Grosholz et al., 2020). While most studies focus on entrepreneurship education in college degree settings (Lourenço, Jones, \& Jayawarna, 2013), some also focus on professional programs (Dakung et al., 2017). The main objective of most research on entrepreneurship education is to investigate the impact of entrepreneurship education programs on individual intentions to act entrepreneurially and business performance that these students make for these educational programs (Walter \& Block, 2016). First, entrepreneurship education programs provide knowledge about some of the aspects that make new businesses viable (Pache \& Chowdhury, 2012). These aspects, for example, include entrepreneurial characteristics such as entrepreneurial mindset, development of entrepreneurial intentions, identification and analysis of opportunities, business planning, new business financing, and business management and growth (Downing, 2012; Sirelkhatim \& Gangi, 2015). This knowledge of entrepreneurship can increase the effectiveness of entrepreneurial skills for each individual such as the belief that people can successfully carry out tasks when setting up a new business (Cooney,2012; Fellnhofer, 2019; Kerrick, Cumberland \& Choi, 2016; Allen \& White-Smith, 2014), hence increasing their entrepreneurial intentions (Strachan, 2018; Balabuch et al., 2019; Aff \& Geissler, 2014). Thus, we propose the following hypothesis:

H1 Entrepreneurship education in LPKA Batam, Pangkalpinang, Medan has a positive and significant influence on their juvenile prisoners' entrepreneurial intention

In addition to the relationship between entrepreneurship education and the development of entrepreneurial competencies, research shows that compared to other occupations, entrepreneurship education can increase people's entrepreneurial attitude once they can perceive that entrepreneurship is a desirable career path. For example, Kisubi, Bonuke\& Korir (2021) found that entrepreneurship education strongly influences entrepreneurial attitudes. Research findings confirming the influence of entrepreneurship education on entrepreneurial attitudes have also been supported by several experts (Jones et al, 2010; Tshikovhi\& Shambare, 2015). Moreover, triggering by the theory of Ajzen (1991) that attitude is people's characters to assess their precise objectives in which it can generate their behavioral intentions, several research then also discover that people's entrepreneurial attitude influences their entrepreneurial intentions (Do \& Dadvari, 2017; Nguyen et al., 2019;Zaremohzzabieh et al., 2019).

In terms of entrepreneurial intention, according to Do and Dadvari (2017)that it is the condition of people's thought which leads their consideration and individual experience to thoughtful commercial actions. Several research also confirm that entrepreneurial attitude influences entrepreneurial intentions (Ismail, Jaffar, \& Hooi, 2013; Miralles, Giones, \& Riverola, 2016; Solesvik, 2013).Thus, we propose the following hypothesis:

H2 Entrepreneurship education in LPKA Batam, Pangkalpinang, Medanhas a positive and significant influence on their juvenile prisoners' entrepreneurial attitude

H3 Entrepreneurial attitude in LPKA Batam, Pangkalpinang, Medanhas a positive and significant influence on their juvenile prisoners' entrepreneurial intention 


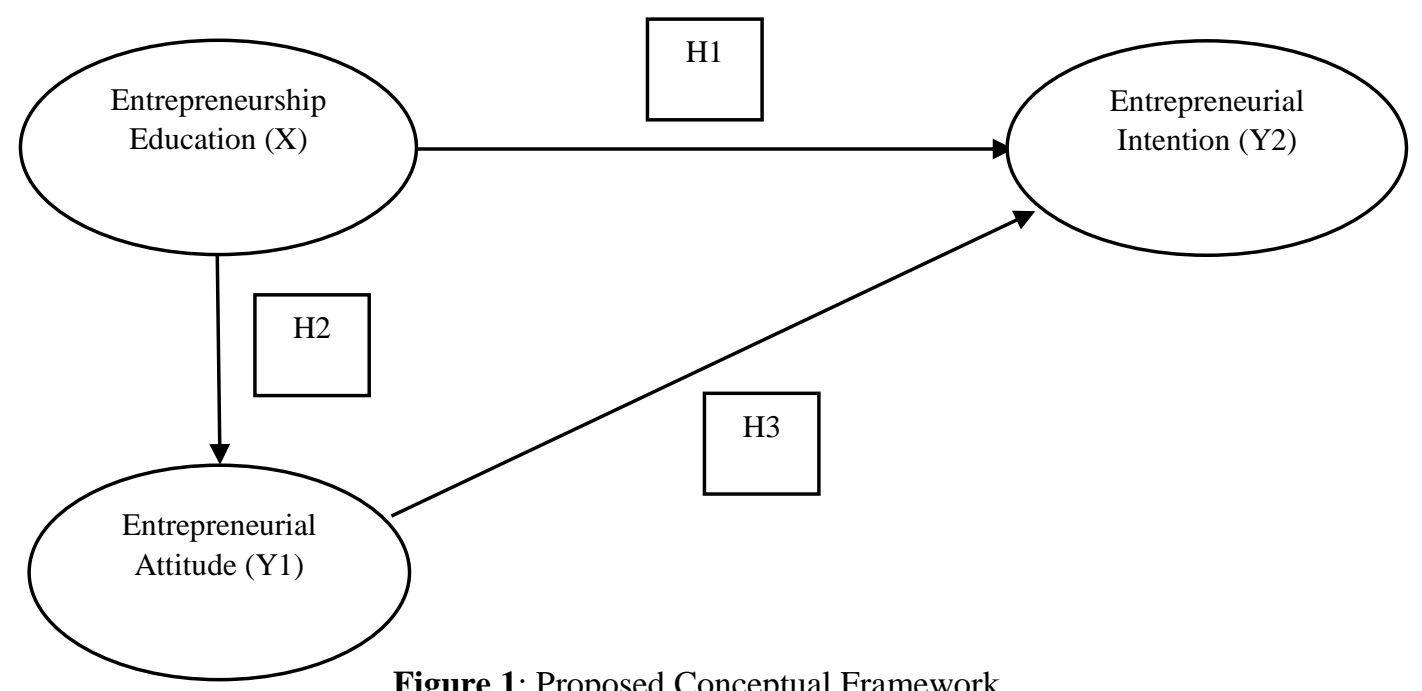

Figure 1: Proposed Conceptual Framework

\section{METHODOLOGY}

The data collection method in this study was a quantitative approach (questionnaire) where the respondent selection technique used purposive sampling. 17 statements of questionnaires were designed and distributed to the entire population of prisoners in 3 provinces, namely the Ministry of Law and Human Rights in the Riau Islands region (10 inmates at LPKA Batam), the Ministry of Law and Human Rights in the Bangka Belitung region (12 inmates at LPKA Pangkalpinang) and the Ministry of Law and Human Rights in the North Sumatra region (8 prisoners at LPKA Medan). Thus, the total population is the same as the number of samples from those three LPKA in the regions. There are 6 statements of entrepreneurship education, 5 statements of entrepreneurial attitude, and 6 statements of entrepreneurial intention which juvenile prisoners examined using a fivepoint Likert scale, where 1 represented strongly disagree and 5 represented strongly agree. The data was then analysed utilizing partial least squares (PLS) to examine the influence of entrepreneurship education on juvenile prisoners' entrepreneurial intentions mediated by entrepreneurial attitude.

Even though these three LPKA are difficult to access by outsiders, this research collaborated with a Civil Society Organisation called Punya Harapan. Punya Harapan is a partner of British Embassy Jakarta who can provide access to LPKA as the object of this research. The desire to examine the entire population of respondents in the research's object was also the determinant of the choice of these 3 prisons. It is expected that this research will find out whether entrepreneurship education in these three prisons in three provinces will have a strong influence on the juvenile inmates' entrepreneurial intention to start businesses independently. In addition, this research is also expected to provide information of the role of entrepreneurial attitude to mediate the relationship between entrepreneurship education and entrepreneurial intention. The findings of the research are expected to be the resource for Indonesian government to improve the quality of entrepreneurship education. It is also expected that the results of the study will influence the development of Indonesian government's policies make entrepreneurship education sustainable for the entire juvenile prisons in Indonesia. The findings of the roles of entrepreneurship education and the mediating role of entrepreneurial attitude on juvenile prisoners' entrepreneurial intention are also projected to contribute for further research to be able to enrich information about assumptions, belief systems, motivation, and self-regulation abilities, entrepreneurial behaviour change, increase the ability to identify and develop business opportunities and make independent business choices as career choices.

\section{DISCUSSION AND RESULTS}

Entrepreneurship education and entrepreneurial attitudes were found to have an impact on the entrepreneurial intentions of child prisoners in LPKA Batam, LPKA Pangkalpinang, and LPKA Medan located in the provinces of Riau the Island, Bangka Belitung the Island, and North Sumatera. The juvenile prisoners responded to questionnaires on how entrepreneurship education giving them a goal setting opportunity, evaluation opportunity, the development of self-ability opportunity, learning useful skills opportunity, understanding business opportunity, and developing business ideas opportunity.

Regarding entrepreneurial attitude, juvenile prisoners gave their assessment whether being an entrepreneur would provide more advantages than disadvantages for them, an attractive career choice for them, have a desire to start a business if they have the resources and opportunities, provides great satisfaction and prefers to be an entrepreneur even though they have many job options.

With respect to entrepreneurial intentions, juvenile inmates gave their responses that they are ready to do anything to be an entrepreneur, decide that entrepreneurship is a career 
goal, make every effort to start their own business, are determined to create a company, have a strong intention to start a business in the near future, and thinking very seriously about starting a business.

To determine the role of the mediating variable, whether complete or partial mediation, it is necessary to analyze the difference in coefficients. The approach to the analysis of the difference in coefficients in this study was carried out twice, namely without the mediating variable (figure 2) and with the mediating variable (figure 3 ). The first step in this approach is to assess the direct effect of the independent variable on the dependent variable in the model without a mediating variable (figure 2). Second, to assess the influence of independent variables on the dependent variable in a model by involving the mediating variable (figure 3 ). Third, to assess the effect of the mediating variable on the dependent variable (figure 3 ). Figure 2 below shows a positive and significant relationship $(\mathrm{p}<0.01 ;=0.43)$ of the entrepreneurship education variable $(\mathrm{X})$ on entrepreneurial intention (Y2) without a mediating variable.

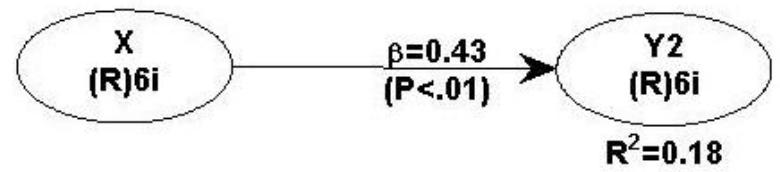

Figure 2: Output Data PLS Analysis without a Mediated Variable

Meanwhile, it is clear from Figure 3 that the independent variable (entrepreneurship education) was found to significantly influence the inmates' entrepreneurial attitude ( $\mathrm{p}<0.01$ and $=0.57)$. Thus, $\mathrm{H} 2$ is accepted. Likewise, the relationship between the values of entrepreneurial attitude and entrepreneurial intention was also found to be significant $(\mathrm{p}=0.01,=0.36)$ which confirms the acceptance of the entrepreneurial attitude variable as a mediating variable between the entrepreneurship education variable and the entrepreneurial intention variable. Nevertheless, further assessment is required to determine whetherjuvenile prisoners' entrepreneurial attitude is a complete or partial mediating variable.

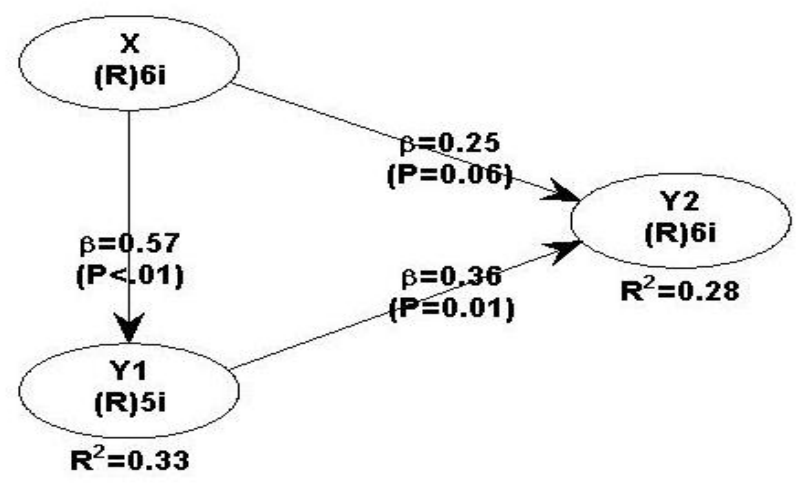

Figure 3: Output Data PLS Analysis with a Mediated Variable
Hence, it is required to compare the coefficient values between figure 2 and 3. The results of the model analysis in figure 2 show that the coefficient value without mediating variables entrepreneurship education $(\mathrm{X})$ to entrepreneurial intention (Y2) is 0.43 , and the coefficient was reduced to 0.25 in a model with a mediating variable in Figure 3 . It is also noticeable from figure 3 , the influence of entrepreneurship education $(\mathrm{X})$ on entrepreneurial intention (Y2) through entrepreneurial attitude (Y1) is significant ( $\mathrm{p}$ $0.01 ;=0.57)$ and $(\mathrm{p}=0.01 ;=0.36)$, but the effect of entrepreneurship education on entrepreneurial intention directly is not significant ( $\mathrm{p}=0.06 ;=0.25$ ). Based on Hair et al. (2010) that it is not a mediating variable if the relationship between the independent variable and the dependent variable remains significant and does not change in value after the mediating variable is added. If the coefficient value decreases but the relationship between the independent variable and the dependent variable remains significant, then this is a partial mediating variable. Meanwhile, it is complete mediation if the coefficient is reduced and the relationship of the independent variable to the dependent variable becomes insignificant after adding the mediating variable. Therefore, entrepreneurial attitude is a complete mediating variable between entrepreneurship education (Y1) and entrepreneurial intention (Y2) which means that $\mathrm{H} 3$ is accepted.

Although entrepreneurship education was found to have a positive effect on entrepreneurial intention, based on figure 3 , the effect was not significant on entrepreneurial intention ( $p=0.06$ and $=0.25$ ). Therefore, $\mathrm{H} 1$ is rejected. Thus, it is clear that entrepreneurship education has an indirect effect on entrepreneurial intention.

Table 1: Latent Variable Coefficients Output

\begin{tabular}{|l|l|l|l|}
\hline & X & Y1 & Y2 \\
\hline R-squared & & 0.330 & 0.283 \\
\hline Composite reliab. & 0.839 & 0.832 & 0.848 \\
\hline Cronbach's alpha & 0.768 & 0.746 & 0.781 \\
\hline Avg.var.extrac. & 0.468 & 0.500 & 0.493 \\
\hline Full Collin. VIF & 1.301 & 1.475 & 1.225 \\
\hline Q-squared & & 0.359 & 0.272 \\
\hline
\end{tabular}

The table above shows that the R-squared for entrepreneurial attitude (Y1) is 0.330 which means that the influence of entrepreneurship education on entrepreneurial attitude is $33 \%$ and the remaining $67 \%$ is influenced by other variables that are outside this research model. Meanwhile, the R-square of the entrepreneurial intention (Y2) is 0.283 , which means that the influence of entrepreneurship education and entrepreneurial attitude on entrepreneurial intention is $28.3 \%$ and the remaining $71.7 \%$ is influenced by other variables out of the research model. Except for average variance extracted (AVE), the 
requirements for reliability, validity, multicollinearity and predictive validity were met with $>0.70,<3.3$ where $<5$ were accepted respectively and they were greater than 0 . Interestingly, according to Fornell and Larcker (1981) and Lam (2012) that the convergent validity of the construct would still be sufficient even though some of the AVE's values are below 0.5 with the condition that the composite reliability of the research is greater than 0.6 as indicated in the table that this research has.

Table 2: Latent variable correlations

\begin{tabular}{|l|l|l|l|}
\hline & $\mathbf{X}$ & Y1 & Y2 \\
\hline $\mathbf{X}$ & $\mathbf{( 0 . 6 8 4 )}$ & 0.476 & 0.262 \\
\hline Y1 & 0.476 & $\mathbf{( 0 . 7 0 7 )}$ & 0.423 \\
\hline Y2 & 0.262 & 0.423 & $\mathbf{( 0 . 7 0 2})$ \\
\hline
\end{tabular}

Note: Square roots of average variances extracted (AVEs) shown on diagonal

Table 3: P Values for Correlations

\begin{tabular}{|l|l|l|l|}
\hline & $\mathbf{X}$ & Y1 & Y2 \\
\hline $\mathbf{X}$ & 1.000 & 0.008 & 0.162 \\
\hline Y1 & 0.008 & 1.000 & 0.020 \\
\hline Y2 & 0.162 & 0.020 & 1.000 \\
\hline
\end{tabular}

Tables 2 and 3 present the correlation coefficients among variables with $p$-values that are important for assessing discriminant validity. The table above presents that the validity for entrepreneurship education, entrepreneurial attitude, and entrepreneurial intention is fulfilled where the square roots of AVE are higher than the correlation among variables in the same column.

The purpose of this study was to examine the influence of entrepreneurship education on juvenile prisoners' entrepreneurial intentions in 3 provinces (Riau the Island, Bangka Belitung the Island, and North Sumatera) in Indonesia and whether entrepreneurial attitude mediates entrepreneurship education for entrepreneurial intentions. The relationship model as illustrated by figure 2 above shows the relationship between the variables of entrepreneurship education, entrepreneurial attitude and entrepreneurial intention.

It was found that entrepreneurship education has a significant relationship with entrepreneurial attitude which supports the findings of Hattab (2014), however, the direct relationship with entrepreneurial intention is not significant. Accordingly, this presents that the entrepreneurial education of juvenile prisoners in these 3 provinces does not directly affect their entrepreneurial intention. Nevertheless, entrepreneurship education is mediated by entrepreneurial attitude and then leads to stronger entrepreneurial intentions. This complete mediating role demonstrates that their entrepreneurial intention is only created when entrepreneurship education first forms their entrepreneurial attitude which opposes the findings of Kisubi, Bonukeand Korir (2021) stating that entrepreneurial attitude is a partial mediating variable between the two variables mentioned. Besides, juvenile prisoners in these 3 provinces find entrepreneurship education useful for them when they have more opportunities to set their business goals and objectives, evaluate and develop their own abilities, learn useful skills, understand business opportunities, and develop business ideas which confirm the findings found in studies by Drost and McGuire (2011).Juvenile prisons in Indonesia should learn from this research that entrepreneurial attitude of juvenile prisoners can be improved by increasing the quality of entrepreneurship education so that juvenile prisoners in Indonesia have more opportunities to learn to set their measurable targets of starting a business, understand the most effective way to self-evaluate, comprehend how to develop their own abilities, choose to learn useful skills which they enjoy, understand business opportunities and act to seize business opportunities and understand how to develop business ideas.

Lastly, entrepreneurial attitude has a significant positive effect on entrepreneurial intention. It is indicated in figure 2 that the R-squared for entrepreneurial attitude is 0.33 which indicates that with only 1 independent variable (entrepreneurship education), it has a major influence on entrepreneurial attitude by contributing 33\% while the rest is influenced by other factors outside the scope of this study. While the R-squared for entrepreneurial intention is 0.283 which presents that when mediated by entrepreneurial attitude, entrepreneurship education has an influence value on entrepreneurial intention of $28.3 \%$ while the rest is influenced by other factors that are outside the scope of the research model. This demonstrates that the entrepreneurial intention of young prisoners in these 3 provinces significantly occurs through their entrepreneurial attitude. Juvenile prisons in Indonesia should learn from this research that they are able develop the entrepreneurial intention of young prisoners by increasing the entrepreneurial attitude of juvenile prisoners by convincing them that being an entrepreneur will provide more advantages than disadvantages for them, being an entrepreneur is an attractive career choice for them, growing their desire to start a business by teaching them how they can have the opportunities and resources they need to become entrepreneurs, and increasing their entrepreneurial attitude should be able to elaborate attractive benefits, clear reasons and great satisfaction for juvenile prisoners to be able to choose to become entrepreneurs despite having many job options.

\section{CONCLUSION}

This study discovers that juvenile prisons in Indonesia can increase the entrepreneurial intention of their juvenile prisoners by increasing their entrepreneurial attitude through 
improving the quality of entrepreneurship education for young prisoners. Entrepreneurship education for juvenile prisoners includes goal setting opportunities, evaluation opportunities, self-ability development opportunities, learning useful skills opportunities, business opportunities, and business ideas development opportunities. Juvenile prisons in Indonesia in general and in these 3 provinces in particular must also learn from this research findings that entrepreneurial intention will only be achieved through the formation of the entrepreneurial attitude of juvenile prisoners. Entrepreneurial attitude will be formed through understanding that the entrepreneurial profession is more profitable with respect to young prisoners' condition, an attractive career choice, encouraging to start a business if have opportunities and resources, providing great satisfaction and choosing to be an entrepreneur despite having many job options.

By knowing the influence of entrepreneurship education on entrepreneurial intention through entrepreneurial attitude, the Indonesian government, society, academicians and entrepreneurs with social responsibility can play a role in encouraging and participating in the fulfillment of entrepreneurship education in juvenile prisons in Indonesia to increase entrepreneurial attitude which will lead to increased entrepreneurship intentions of juvenile prisoners in Indonesia.

\section{REFERENCES}

1. Aff, O., \& Geissler, G. (2014). Entrepreneurship Education. Becoming an Entrepreneur, 17-33.

2. Ajzen I. (1991). The theory of planned behavior. Organizational Behavior and Human Decision Processes, 50, 179-211

3. Allen, Q., \& White-Smith, K. A. (2014). Just as bad as prisons: The challenge of dismantling the school-to-prison pipeline through teacher and community education. Equity \& Excellence in Education, 47(4), 445-460.

4. Balabuch, P., De Francisco, A. C., Pinheiro, E., Sokulski, C. C., \& Aires, J. P. (2019). Developing Professional Skills of the Convict through Entrepreneurship Education. Creative Education, 10(13), 3329-3344.

5. Cooney, T. M. (2012). Reducing recidivism through entrepreneurship programmes in prisons. The International Journal of Entrepreneurship and Innovation, 13(2), 125-133.

6. Dakung, R. J., Orobia, L., Munene, J. C., \& Balunywa, W. (2017). The role of entrepreneurship education in shaping entrepreneurial action of disabled students in Nigeria. Journal of Small Business \& Entrepreneurship, 29(4), 293-311.

7. Do, B.R. \& Dadvari, A. (2017). The influence of the dark triad on the relationship between entrepreneurial attitude orientation and entrepreneurial intention: A study among students in Taiwan University. Asia Pacific Management Review, 22(4), 85-191.

8. Downing, C. (2012). Bolivian prison entrepreneurship: An unexpectedly successful rehabilitation method? Journal of Enterprising Communities: People and Places in the Global Economy, 6(4), 339-349.

9. Drost, E.A. \& McGuire, S. J. J. (2011). Fostering Entrepreneurship among Finnish Business Students: Antecedents of Entrepreneurial Intent and Implications for Entrepreneurship Education. International Review of Entrepreneurship, 9(2), 130.

10. Fellnhofer, K. (2019). Toward a taxonomy of entrepreneurship education research literature: A bibliometric mapping and visualization. Educational Research Review, 27, 28-55.

11. Fornell, C., \& Larcker, D. F. (1981). Structural Equation Models with Unobservable Variables and Measurement Error: Algebra and Statistics. Journal of Marketing Research, 18, 382-388.

12. Grosholz, J. M., Kabongo, J. D., Morris, M. H., \& Wichern, A. (2020). Entrepreneurship Education in the Transformation of Incarcerated Individuals: A Review of the Literature and Future Research Directions. International Journal of Offender Therapy and Comparative Criminology,64(15), 1551-1570.

13. Hair, J. F., Black, W. C., Babin, B. J., Anderson, R. E., \& Tatham, R. L. (2009). Multivariate Data Analysis (7th ed.). Upper Saddle River, New Jersey: Pearson Education Limited.

14. Hattab, H. W. (2014). Impact of entrepreneurship education on entrepreneurial intentions of university students in Egypt. The Journal of Entrepreneurship, 23(1), 1-18.

15. Hussain A., \& Norashidah H. (2015). Impact of entrepreneurial education on entrepreneurial intentions of Pakistani students. Journal of Entrepreneurship and Business Innovation, 2(1):43.

16. Ismail, N., Jaffar, N., \& Hooi, T. S. (2013). Using EAO model to predict the self-employment intentions among the Universities' Undergraduates in Malaysia. International Journal of Trade, Economics and Finance, 4(5), 282.

17. Jones, P., Packham, G., Pickernell, D. \& Miller, C. J. \& Thomas, B. (2010). Attitudes towards entrepreneurship education: A comparative analysis. Education and Training,52(8/9), 568-586. 
18. Kerrick, S. A., Cumberland, D. M., \& Choi, N. (2016). Comparing military veterans and civilians responses to an entrepreneurship education program. Journal of Entrepreneurship Education, 19(1), 9

19. Kisubi, M., Bonuke, R. \& Korir, M. (2021). The Impact of Entrepreneurship Education and Entrepreneurial Attitude on Entrepreneurial Intentions among Undergraduate Students in Uganda. Journal of Management and Business Review,23(2) 1-15.

20. Lam, L. W. (2012). Impact of competitiveness on salespeople's commitment and performance. Journal of Business Research, 65(9), 1328-1334.

21. Lourenço, F., Jones, O., \& Jayawarna, D. (2013). Promoting sustainable development: The role of entrepreneurship education. International Small Business Journal, 31(8), 841-865.

22. Miralles, F., Giones, F., \& Riverola, C. (2016). Evaluating the impact of prior experience in entrepreneurial intention. International Entrepreneurship and Management Journal, 12(3), 791-813.

23. Nguyen, A.T., Do, T.H.H., Vu, T.B.T., Dang, K.A., Nguyen, H.L. (2019). Factors affecting entrepreneurial intentions among youths in Vietnam. Children and Youth Services Review, 99,186-193.

24. Pache, A. C., \& Chowdhury, I. (2012). Social entrepreneurs as institutionally embedded entrepreneurs: Toward a new model of social entrepreneurship education. Academy of Management Learning \& Education, 11(3), 494510.

25. Sirelkhatim, F., \& Gangi, Y. (2015). Entrepreneurship education: A systematic literature review of curricula contents and teaching methods. Cogent Business \& Management, 2(1), 1052034.

26. Solesvik, M. Z. (2013). Entrepreneurial motivations and intentions: investigating the role of education major. Education + Training, 55(3), 253-271.

27. Strachan, G. (2018). Can education for sustainable development change entrepreneurship education to deliver a sustainable future?. Discourse and Communication for Sustainable Education, 9(1), 36-49.

28. Tshikovhi, N., \& Shambare, R. (2015). Entrepreneurial knowledge, personal attitudes, and entrepreneurship intentions among South African Enactus students. Problems and Perspectives in Management, 13(1), 152-158.

29. Walter, S. G., \& Block, J. H. (2016). Outcomes of entrepreneurship education: An institutional perspective. Journal of Business venturing, 31(2), 216-233.

30. Zaremohzzabieh, Z., Ahrari, S., Krauss, S.E., Samah, A.B.A., Meng, L.K., Ariffin, Z. (2019). Predicting social entrepreneurial intention: A metaanalytic path analysis based on the theory of planned behavior. Journal of Business Research, 96, 264-276. 